ВИКОРИСТАННЯ ФІКСОВАНИХ ПОДВІЙНИХ І ПОТРІЙНИХ КОМБІНАЦІЙ У ДОСЯГНЕННІ ЦІЛЬОВОГО РІВНЯ АРТЕРІАЛЬНОГО ТИСКУ ПРИ ДОБОВОМУ МОНІТОРУВАННІ У ПАЦІЕНТІВ 3 АРТЕРІАЛЬНОЮ ГІПЕРТЕНЗІЕЮ

\author{
О.Л. Рековещь, Ю.М. Сіренко, О.О. Торбас, С.М. Кушнір, Г.Ф. Примак
}

ДУ “ННЦ “Інститут кардіології імені академіка М.Д. Стражеска” НАМН України, м. Київ, Україна

Ключові слова:

артеріальна

гіпертензія, валсартан, амлодипін, фіксовані подвійні та потрійні комбінаиії, добове моніторування артеріального тиску, ефективність.

Буковинський медичний вісник. T.24, № 2 (94). C. 102-113.

DOI:

10.24061/2413-0737.

XXIV.2.94.2020.50

E-mail: recovets@ukr.net
Мета роботи - оцінити терапевтичну ефективність фіксованої потрійної комбіначії валсартан/амлодипін/гідрохлортіазид порівняно з подвійною фіксованою комбінацією валсартан/амлодипін у лікуванні пацієнтів із артеріальною гіпертензією II-III ступеня.

Матеріал і методи. У дослідження увійшли 50 пацієнтів із АГ 2-3-го ступеня. Проводили офісне вимірювання АТ, ДМАТ, біохімічне дослідження крові. Оцінку проводили на початку та через три місяці терапіі. У дослідження включались пацієнти з помірною та тяжкою артеріальною гіпертензією без иукрового діабету. Пацієнтів розподілили на дві групи. Пацієнтам першої групи (n=25) призначена фіксована потрійна комбінація 160 мг валсартану/5 мг амлодипіну/12,5 мг гідрохлортіазиду один раз на добу, враниі, протягом одного місяия. Пацієнти другої групи (n=25) отримували за аналогічною схемою подвійну фіксовану комбінацію 160 мг валсартану/ 5 мг амлодипіну один раз на добу, враниі, протягом одного місяия. За необхідності, якщо не досягнено иільового рівня офісного АТ менше 140/90 мм рт. cm., доза титрувалась до добової дози 320/10/12,5 мг (валсартан/ амлодипін/гідрохлортіазид) на фіксованій потрійній комбіначії та до 320/10 мг (валсартан/амлодипін) на фіксованій подвійній комбінації. Через три місяиі лікування відбувався контроль терапії.

Результати. Середній вік хворих склав [54,9 \pm 1,8 (25-75)] років. Середній IMT - 31,2 \pm 0,7 кг/м2. Середні иифри офісного САТ та ДАТ на початку дослідження становили $161,7 \pm 1,8$ мм рт.cm. та 98,5 $\pm 1,4$ мм рт.ст. відповідно. Середня офісна ЧСС - 70,7 $\pm 1,4$ уд/хв. Середні рівні АТ при амбулаторному моніторуванні становили для

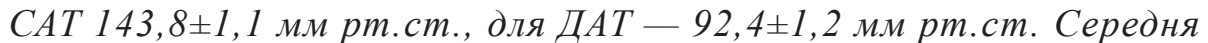
добова ЧСС - 71,5 1, 5 уд/хв. Зниження середньодобового АТ склало 18,0/16,1 мм рт. cm. (p<0,05) на подвійній (вал/амл) та 23,8/20,7 мм pm.cm. $(p<0,05)$ на потрійній (вал/амл/ГХТ) комбінації. Зниження середньоденного АТ склало 19,4/17,8 мм рт. cm. $(p<0,05)$ на подвійній (вал/амл) та 17,8/22,6 мм рт.ст. ( $<<0,05)$ на потрійній (вал/амл/ГХТ) комбінації. Зниження середньонічного АТ склало 17,0/12,1 мм рт. cm. $(p<0,05)$ на подвійній (вал/амл) та 20,5/18,2 мм pm.cm. $(p<0,05)$ на потрійній (вал/амл/ГХТ) комбіначії. Досягнення цільового АТ при добовому моніторуванні становило 77,3\% - у подвійній комбінації та 95,2\%- у потрійній комбінації.

Висновки. Потрійна комбіначія валсартан/амлодипін/حідрохлортіазид була більш ефективною в зниженні артеріального тиску при добовому моніторуванні порівняно з подвійною комбінацією валсартан/ амлодипін, щз не супроводжувалось збільшенням побічних ефектів. 
Original research

ИСПОЛЬЗОВАНИЕ ФИКСИРОВАННЫХ ДВОЙНЫХ И ТРОЙНЫХ КОМБИНАЦИЙ В ДОСТИЖЕНИИ ЦЕЛЕВОГО УРОВНЯ АРТЕРИАЛЬНОГО ДАВЛЕНИЯ ПРИ СУТОЧНОМ МОНИТОРИРОВАНИИ У ПАЦИЕНТОВ С АРТЕРИАЛЬНОЙ ГИПЕРТЕНЗИЕЙ

\author{
О.Л. Рековец, Ю.Н. Сиренко, А.А. Торбас, С.Н. Кушнир, Г.Ф. Примак
}

ГУ "ННЦ" Институт кардиологии имени академика Н.Д. Стражеско "НАМН Украины, г. Киев, Украина

\author{
Ключевые слова: \\ артериальная \\ гипертензия, \\ валсартан, амлодипин, \\ фиксированные \\ двойные и тройные \\ комбинации, суточное \\ мониторирование \\ артериального \\ давления, \\ эффективность.
}

Буковинский медицинский вестник. T.24, № 2 (94). С. 102-113.
Цель работы - оценить терапевтическую эффективность фиксированной тройной комбинацчи валсартан / амлодипин / гидрохлоротиазид в сравнении с двойной фиксированной комбинацией валсартан / амлодипин в лечении пациентов с артериальной гипертензией II-III степени.

Материал и методы. В исследование было включено 50 пацчентов с АГ 2-3-ей степени. Проводили офисное измерение АД, СМАД, биохимическое исследование крови. Оценку проводили в начале и через три месяца терапии. В исследование включались пациенты с умеренной и тяжелой артериальной гипертензией без сахарного диабета. Пациенты были разделены на две группь. Первой группе $(n=25)$ была назначена фиксированная тройная комбинация 160 мг валсартана / 5 мг амлодипина / 12,5 мг гидрохлоротиазида один раз в сутки, утром, в течение одного месяца. Пациченты второй группь $(n=25)$ получали двойную фиксированную комбинацию 160 мг валсартана / 5 мг амлодипина один раз в сутки, утром, в течение одного месяца. При необходимости, если не было достижения целевого уровня офисного АД менее 140/90 мм рт. ст., доза титровалась до суточной дозы 320/10/12,5 мг (валсартан / амлодипин / гидрохлоротиазид) на фиксированной тройной комбинации и до 320/10 мг (валсартан ( амлодипин) на фиксированной двойной комбинации. Через три месяца лечения происходил контроль терапии.

Результатыл. Средний возраст больных составил [54,9 \pm 1,8 (25-75)] лет. Средний ИМТ - 31,2 \pm 0,7 кг / м2. Средние ичифры офисного САД и ДАД в начале исследования составили 161,7 $\pm 1,8$ мм рт.ст. и 98,5 $\pm 1,4$ мм рт.ст. соответственно. Средняя офисная ЧСС - 70,7 $\pm 1,4$ уд / мин. Средние уровни АД при амбулаторном мониторировании составили САД

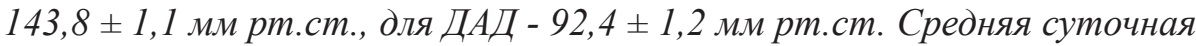
ЧСС - 71,5 $\pm 1,5$ уд / мин.

Снижение среднесуточного АД составило 18,0 / 16,1 мм pm. cm. $(p<0,05)$ на двойной (ВАЛ / АМЛ) и 23,8 / 20,7 мм рт.ст. ( $p<0,05)$ на тройной (ВАЛ / АМЛ / ГХТ) комбинаичи. Снижение среднедневного АД составило 19,4 / 17,8 мм рт. cm. (p <0,05) на двойной (ВАЛ / АМЛ) и 17,8 / 22,6 мм pm.cm. $(p<0,05)$ на тройной (ВАЛ / АМЛ / ГХТ) комбиначчи. Снижение средненочного АД составило 17,0 / 12,1 мм рт. cm. $(p<0,05)$ на двойной (ВАЛ / АМЛ) и 20,5 / 18,2 мм рт.cm. ( $<$ <0,05) на тройной (ВАЛ / АМЛ / ГХТ) комбинации. Достижения цуелевого АД при суточном мониторировании составило 77,3\% - в двойной комбиначии и 95,2\% - в тройной комбинации. Выводы. Тройная фиксированная комбинация валсартан / амлодипин / гидрохлортиазид была более эффективной в снижении артериального давления при суточном мониторировании по сравнению с двойной фиксированной комбинацией валсартан / амлодипин, что не сопровождалось увеличением побочных эффектов. 
Оригінальні дослідження

\title{
USE OF FIXED DOUBLE AND TRIPLE COMBINATIONS IN ACHIEVEMENT OF TARGET LEVEL OF AMBULATORY BLOOD PRESSURE IN PATIENTS WITH ARTERIAL HYPERTENSION
}

\author{
O.L. Rekovets, Yu.M. Sirenko, O.O. Torbas, S.M. Kushnir, G.F. Primak
}

DN "NSC" Institute of Cardiology named after acad. MD Strazhesko "NAMS of Ukraine, Kyiv, Ukraine

Key words: arterial hypertension, valsartan, amlodipine, fixed double and triple combination, ambulatory blood pressure monitoring, efficacy.

Bukovinian Medical Herald. V.24, № 2 (94.) P. 102-113.
The objective of the research - to evaluate the therapeutic efficacy of the generic combination (a fixed triple combination of valsartan / amlodipine / hydrochlorothiazide compared with a double fixed combination of valsartan / amlodipine) in the treatment of patients with arterial hypertension II-III degree. The objectives of the study were: to study the therapentic efficacy on ambulatory BP of a fixed triple and double combination in the treatment of arterial hypertension.

Material and methods. The study included 50 patients with 2-3 grade hypertension. The office measurement of BP, ABMP, biochemical blood tests before and after 3 months fixed combination therapy val/aml or val/aml/HTZ. The study included patients with moderate and severe arterial hypertension without diabetes. Patients were divided into 2 groups. The first group $(n=25)$ received fixed triple combination of $160 \mathrm{mg}$ valsartan / $5 \mathrm{mg}$ amlodipine / 12.5 $m g$ hydrochlorothiazide once daily, in the morning for 1 month. Patients in the second group $(n=25)$ received a double fixed combination of $160 \mathrm{mg}$ valsartan I $5 \mathrm{mg}$ amlodipine once a day, in the morning for 1 month. When necessary, if there was no achievement of the target level of office blood pressure $<140 / 90$ $\mathrm{mm} \mathrm{Hg}$, the dose was titrated to a daily dose of 320/10 / $12.5 \mathrm{mg}$ (valsartan / amlodipine / hydrochlorothiazide) on a fixed triple combination and up to 320/10 mg (valsartan / amlodipine) on a fixed double combination. After three months of treatment, therapy was monitored.

Results. The average age of patients was $54.9 \pm 1.8(25-75)$ years. The average $B M I$ was $31.2 \pm 0.7 \mathrm{~kg} / \mathrm{m} 2$. The average of office $S B P$ and DBP at the beginning of the study were $161.7 \pm 1.8 \mathrm{~mm} \mathrm{Hg}$ and $98.5 \pm 1.4 \mathrm{mmHg}$. The average office heart rate was $70.7 \pm 1.4$ beats / min. The mean 24 blood pressure monitoring was $143.8 \pm 1.1 \mathrm{~mm} \mathrm{Hg}$ for $S B P$ and $92.4 \pm 1.2 \mathrm{~mm} \mathrm{Hg}$ for DBP. The average daily heart rate was $71.5 \pm 1.5$ beats / min. The decrease in average $24 B P$ was $18.0 / 16.1 \mathrm{~mm} \mathrm{Hg}(p<0,05)$ on double combination (val/aml) and 23,8 / 20,7 $\mathrm{mm} \mathrm{Hg}(p<0,05)$ on the triple combination (val/aml/HTZ). The decrease mean day time blood pressure was $19.4 / 17.8 \mathrm{~mm} \mathrm{Hg}(p<0,05)$ on double (val/aml) and 17,8/22,6 $\mathrm{mm} \mathrm{Hg}(p<0,05)$ on the triple combination (val/aml/HTZ). Decrease mean nocturnal blood pressure were $17.0 / 12.1 \mathrm{~mm} \mathrm{Hg} .(p<0,05)$ on double (val/aml) and 20,5 / 18,2 $\mathrm{mm} \mathrm{Hg}(p<0,05)$ on the triple (val/aml/ $H T Z$ ) combination. Achievement of target BP at ABPM was $77.3 \%$ - in the double (val/aml) combination and $95.2 \%$ in the triple (val/aml/HTZ) combination. Conclusions. The triple fixed combination (val/aml/HTZ) was more effective in reducing blood pressure with daily monitoring compared to a double fixed (vall aml) combination which was not accompanied by an increase in side effects.
Вступ. Артеріальна гіпертензія (АГ) є важливою проблемою охорони здоров'я у світі в цілому. Поширеність АГ може зрости з 972 млн. людей у 2000 році до 1,56 млрд. - у 2025 р. [1]. Згідно з рекомендаціями Європейського товариства кардіологів та Европейського товариства 3 гіпертензії у 2018 році для стартової АГ терапії рекомендовано два або більше антигіпертензивних препаратів для контролю АТ у більшості пацієнтів iз АГ [2]. Незважаючи на наявність ефективних антигіпертензивних препаратів та комбінацій лікарських засобів, контроль АТ у популяції залишається поганим, а високий рівень АТ є основною причиною смерті та серцево-судинних захворювань у всьому світі [3].

G. Tocсі зі співавт. [4] досліджували бази даних дорослих амбулаторних пацієнтів, які проходили обстеження в трьох європейських кращих центрах із 
Original research

АГ (Рим, Італія; L'Aquila, Італія; Валенсія, Іспанія). Цільові рівні АТ були визначені відповідно до рекомендацій ESH / ESC 2013 року [5] (<140/90 мм рт.ст. у осіб, які не страждають діабетом, віком від 18 до 80 років, $<150 / 90$ мм рт.ст. у віці $\geq 80$ років та $<140 / 85$ мм рт.ст. у пацієнтів 3 діабетом) або рекомендацій ESC / ESH 2018 року ( $<130 / 80$ мм рт.ст. у осіб віком 18-65 років, $<140 / 80$ мм рт.ст. у осіб віком $65-79$ років і $\geq$ 80 років). Ризик SCORE оцінювали у всіх пацієнтів. У результаті дослідження виявили, що пацієнти з АГ, які приймали АГ препарати, мали значно вищий рівень ризику SCORE $(8,3 \pm 13,0 \%$ проти $3,9 \pm 8,4 \%$; $<<0,001)$ та більш низькі рівні офісного САТ/ДАТ (140,6 $\pm 18,8$ $/ 83,9 \pm 11,5$ проти 148,3 $\pm 14,2$ / 94,7 $\pm 10,1$ мм рт.ст.; $\mathrm{p}<0,001)$, ніж неліковані пацієнти. Порівняно з попередніми рекомендаціями, контроль АТ значно знизився в амбулаторних хворих недіабетиків $(\mathrm{n}=5847)$ усіх вікових груп [18-65 років: (13,1\% проти 42,9\%), 65-79 років $(25,8 \%$ проти $42,5 \%) \mathrm{i} \geq 80$ років $(29,1 \%$ проти $66,0 \%) ; \mathrm{p}<0,001$ для всіх порівнянь]; подібне зниження спостерігалось у пацієнтів із цукровим діабетом $(\mathrm{n}=1245)[18-65$ років $(32,7 \%$ проти $14,8 \%), 65-79$ років $(37,3 \%$ проти $24,7 \%)$ та $\geq 80$ років $(47,1 \%$ проти $27,9 \%) ; \mathrm{p}<0,001]$. Автори дійшли висновку, що згідно з рекомендованими новими цільовими рівнями АТ, відсоток пацієнтів із неконтрольованою АГ значно зріс, а такі результати повинні спонукати до більш жорсткого застосування рекомендацій і підкреслити необхідність вдосконалення стратегій контролю АТ.

Відповідно до сучасних рекомендацій із лікування АГ більшість пацієнтів потребує два або більше антигіпертензивних препаратів для досягнення цільових рівнів AT $[3,6,7]$. Фіксована комбінація за рахунок зменшення кількості препаратів, що повинен приймати пацієнт, покращує його прихильність до лікування. Метааналіз дев'яти досліджень, у яких порівнювали застосування фіксованої комбінації в зіставленні з монотерапією, у лікуванні пацієнтів із цукровим діабетом та АГ, показав $26 \%$ покращення прихильності до лікування на фоні прийому фіксованої комбінації [3,4-8].

У дослідженні ACCOMPLISH у пацієнтів з ізольованою систолічною гіпертензією, фіксована комбінація амлодипіну та беназеприлу знизила на $20 \%$ ризик виникнення комбінованої кінцевої точки розвитку серцево-судинних подій порівняно з гідрохлоротіазидом та беназеприлом з аналогічним зниженням тиску крові у двох групах [11].

У 12-тижневому рандомізованому багатоцентровому дослідженні автори вивчали вплив фіксованої комбінації валсартану/амлодипіну (Вал/Амло) 80/5 мг $(\mathrm{n}=75)$ та ніфедипіну GITS 30 мг $(\mathrm{n}=75)$ на АT при добовому моніторуванні та жорсткість артерій, яку оцінювали за швидкістю поширення пульсової хвилі (ШППХ) у пацієнтів із АГ. Через 12 тижнів лікування комбінація Вал/Амло виявилася більш ефективною, ніж ніфедипін GITS, у зниженні AT у нічний час при стійкій неконтрольованій гіпертензії та зменшенні жорсткості артерій незалежно від зниження АТ [12].
Проведено обсерваційне дослідження використання фіксованої комбінації валсартан/амлодипін при тривалому застосуванні в китайській популяції із досягнення цільового рівня АТ спостерігалося у 74,1\% пацієнтів через рік $(\mathrm{p}<0,0001)$. Побічні ефекти (ПЕ) спостерігалися у 23,3\% пацієнтів. Більшість ПЕ були легкими та помірними, тільки у 0,6\% пацієнтів була відміна валсартану/амлодипіну. Це дослідження доводить, що фіксована комбінація Вал/Амло ефективно знижує АТ протягом тривалого періоду серед пацієнтів із АГ у Китаї, з хорошим профілем прихильності та переносимості [13].

Вимогою до будь-якої комбінації $є$ доведене більш виражене зниження артеріального тиску, ніж при використанні компонентів у монотерапії. Це може бути досягнуто при комбінуванні препаратів, що мають різний механізм дії. Поліпшення переносимості лікування $\epsilon$ ключовим елементом раціонального комбінування лікарських засобів $[14,15]$. Це досягається в тих випадках, коли фармакологічні ефекти одного препарату нейтралізують небажані ефекти іншого. Так, використання комбінації блокатора рецепторів ангіотензину II (БРА ІІ) з дигідропіридиновими АК значно знижує частоту виникнення асоційованих з АК набряків, а також гіпокаліємію, асоційовану з прийомом діуретиків $[16,17]$.

У травні 2009 p FDA схвалило першу потрійну комбінацію Вал/Амло і гідрохлортіазиду (ГХТ) в одній таблетці. Схвалення комбінації Вал/Амло/ГХТ було засновано на результатах проспективного рандомізованого подвійного сліпого дослідження [18], в якому оцінювалася ефективність і безпека щоденного одноразового прийому потрійної комбінації порівняно з трьома варіантами двокомпонентної терапії (Вал/Амло, Вал/ ГХТ або Амло /ГХТ). До кінця дослідження в групі потрійної терапії зниження АТ перевищувало подвійні комбінації більш ніж на 6 мм рт.ст. для САД і 3 мм рт.ст. для ДАТ. Частка пацієнтів, які досягли цільового АТ $<140 / 90$ мм рт.ст., була значно вище в групі потрійної терапії (70,8\% vs 48,3\% у групі Вал/ГХТ, 54,1\% у групі Вал/Амло і 44,8\% у групі Амло/ГХТ, p<0,0001 для всіх груп порівняння). Частота побічних ефектів (ПЕ) істотно не відзрізнялася між групами. Периферійні набряки (найбільш частий ПЕ в групі потрійної терапії) виникали значно рідше, ніж у групі подвійної терапії із застосуванням АК (4,5 і 8,7\% випадків відповідно).

Мета роботи. Оцінити ефективність впливу фіксованих подвійної та потрійної комбінації у зниженні артеріального тиску при добовому моніторуванні в лікуванні пацієнтів із артеріальною гіпертензією IIIII ступеня у вигляді фіксованої потрійної комбінації валсартан/амлодипін/гідрохлортіазид) порівняно з фіксованою подвійною комбінацією валсартан/амлодипін).

Матеріал і методи. У дослідження увійшли 50 пацієнтів із АГ ІІ-ІІІ ступеня за класифікацією ВООЗ, які проходили стаціонарне або амбулаторне лікування у відділенні симптоматичних гіпертензій ДУ “Національного наукового центру «Інститут кардіології імені 
академіка М.Д.Стражеска»" НАМН України. Середній вік хворих склав $[54,9 \pm 1,8(25-75)]$ років. Середня маса тіла становила 92,4 $\pm 2,6$ кг. Середній IMT - 31,2 $\pm 0,7$ кг/м2. Середні цифри офісного САТ та ДАТ на початку дослідження становили $161,7 \pm 1,8$ мм рт.ст. та $98,5 \pm 1,4$ мм рт.ст. відповідно. Середня офісна ЧСС $70,7 \pm 1,4$ уд/хв. Середні рівні АТ при амбулаторному моніторуванні становили для САТ 143,8土1,1 мм рт.ст.,

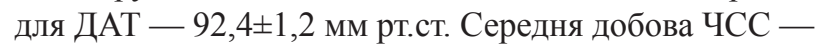
$71,5 \pm 1,5$ уд/хв.

У дослідження включалися пацієнти віком 25-75 років з рівнем систолічного (САТ) та/або діастолічного (ДАТ) АТ > 160/100 мм рт. ст. наприкінці періоду відміни всіх антигіпертензивних препаратів.

У дослідження не включали пацієнтів із рівнем АТ > 220/140 мм рт.ст.; вторинною та злоякісною АГ; цукровим діабетом; наявності в анамнезі інфаркту міокарда, порушень мозкового кровообігу; порушень серцевого ритму (постійна форма фібриляції передсердь, часта шлуночкова або суправентрикулярна екстрасистолія, атріовентрикулярна блокада II та III ступеня, синдром слабкості синусового вузла); серцевої недостатності IIIIV функціонального класу (NYHA); стенокардії напруги III-IV функціонального класу; тромбоемболією легеневої артерії; з анафілактичними реакціями в анамнезі; вираженою хронічною нирковою недостатністю (ШКФ $<30$ мл/хв); з декомпенсованим ураженням печінки; 3 психічними розладами; з онкологічними захворюваннями; вагітні жінки або з лактацією; з підвищеною чутливістю до компонентів терапії в анамнезі; пацієнти, що беруть участь в інших клінічних дослідженнях.

Умовами припинення дослідження були: індивідуальна непереносимість препарату, поява тяжких або неочікуваних побічних реакцій, які потребують на думку дослідника або пацієнта відміни, значне погіршення загального стану в період дослідження, порушення пацієнтом протоколу дослідження, зміни лабораторних показників, які свідчать про потенційну загрозу для пацієнта, відкликання пацієнтом інформованої згоди.

Згідно з протоколом, усім пацієнтами проведені наступні дослідження: збір анамнезу, вимірювання маси тіла та зросту, об'єктивне обстеження, вимірювання офісного САТ та ДАТ, частоти серцевих скорочень (ЧСС), біохімічне дослідження крові, загальноклінічні дослідження крові, добове моніторування АТ (ДМАТ), реєстрація побічних явищ, контроль за виконанням режиму прийому препаратів (табл. 1).

Всім пацієнтам проводили визначення зросту та маси тіла, розраховували індекс маси тіла (IMT = вага(кг)/зріст(м2)). Діагноз надлишкової маси тіла або ожиріння встановлювали відповідно до критеріїв ВООЗ (1997): надлишкову масу тіла встановлювали при значенні IMT від 25 до 29,9 кг/м2, ожиріння I ступеня - IMT від 30 до 34,9 кг/м2, ожиріння II ступеня - IMT від 35 до 39,9 кг/м2, ожиріння III ступеня - IMT $\geq 40,0$ кг/м2.

Вимірювання АТ проводили на апараті Omron M10 (Японія) вранці між восьмою та десятою годинами на всіх етапах дослідження. Реєстрацію САТ та ДАТ у положенні сидячи проводили на одній і тій же руці два рази з інтервалом у дві хвилини, якщо величини АТ не різнилися більш як на 5 мм рт. ст. При виявленні більшої різниці між отриманими величинами - проводили третє вимірювання та обчислювали середнє значення з двох або трьох послідовних вимірювань. ЧСС визначали після другого вимірювання.

ДМАТ проводили на портативному апараті АВРМ04 (“Метідек”, Угорщина) або MobiloGraph (IOM, Hiмеччина) на початку та наприкінці періоду лікування.

Таблиця 1

Протокол дослідження

\begin{tabular}{|c|c|c|c|c|c|}
\hline & Скринінг та & $\begin{array}{l}\text { Рандо- } \\
\text { мізація }\end{array}$ & Лiг & уван & \\
\hline Дані дослідження & 1 & 7 & 30 & 60 & 90 \\
\hline $\begin{array}{c}\text { Візити (точки спосте- } \\
\text { реження) }\end{array}$ & 1 & 2 & 3 & 4 & 5 \\
\hline $\begin{array}{c}\text { Збір анамнезу та } \\
\text { попередня оцінка } \\
\text { відповідності пацієнта } \\
\text { критеріям включення/ } \\
\text { виключення }\end{array}$ & $*$ & & & & \\
\hline $\begin{array}{c}\text { Отримання письмо- } \\
\text { вої згоди на участь у } \\
\text { дослідженні }\end{array}$ & $*$ & & & & \\
\hline $\begin{array}{c}\text { Призначення 7-денно- } \\
\text { го безмедикаментоз- } \\
\text { ного періоду }\end{array}$ & $*$ & & & & \\
\hline $\begin{array}{c}\text { Повторна оцінка } \\
\text { відповідності хворого } \\
\text { критеріям включення/ } \\
\text { виключення }\end{array}$ & & $*$ & & & \\
\hline $\begin{array}{c}\text { Призначення лікуван- } \\
\text { ня }(*) \text { корекція дози } \\
(* *)\end{array}$ & & $*$ & $* *$ & $* *$ & $* *$ \\
\hline $\begin{array}{c}\text { Об’єктивне дослі- } \\
\text { дження: } \\
\text { - вимірювання ЧСС } \\
\text { та АТ } \\
\end{array}$ & * & $*$ & $*$ & $*$ & $*$ \\
\hline $\begin{array}{c}\text { Добове моніторування } \\
\text { АТ } \\
\end{array}$ & & $*$ & & & $*$ \\
\hline $\begin{array}{c}\text { Лабораторні дослі- } \\
\text { дження: } \\
\text { - Загальний аналіз } \\
\text { крові } \\
\text { - агальний аналіз сечі } \\
\text { - Біохімічне дослі- } \\
\text { дження крові }\end{array}$ & $*$ & & & & $*$ \\
\hline $\begin{array}{c}\text { Виявлення та реєстра- } \\
\text { ція можливих побіч- } \\
\text { них реакцій }\end{array}$ & & & \multicolumn{3}{|c|}{ Кожен день } \\
\hline
\end{tabular}

*Примітки:

- Отримання інформованої згоди пацієнта;

- Медична амбулаторна карта пацієнта;

- Фізикальне обстеження;

- Дані об'єктивного дослідження (АТ, ЧСС);

- Попереднє та супутнє лікування;

- Перевірка відповідності критеріям включення/ виключення в дослідженні. 
Original research

Біохімічні аналізи виконували на автоматичному біохімічному аналізаторі "А-25" (Франція) в ДУ «ННЦ «Інститут кардіології імені академіка М.Д.Стражеска» НАМН України до та наприкінці дослідження. Оцінку ефективності лікування проводили на основі динаміки АТ (офісного та добового), а також суб'єктивних скарг хворого. Головними критеріями ефективності були: зниження офісного САТ не менше, ніж на 20 мм рт.ст. та ДАТ не менше, ніж на 10 мм рт.ст. або досягнення цільового рівня САТ/ДАТ (менше 140/90 мм рт.ст.). Вторинними критеріями ефективності були: зниження середніх значень САТ і ДАТ за 24 години, у період сну та в денний період.

Усі дослідження проводили після 7 - денної відміни антигіпертензивних препаратів, які пацієнт отримував до включення у дослідження, та через три місяці лікування. Контроль офісного АТ та реєстрацію побічних явищ проводили на кожному етапі обстеження.

До початку дослідження всім пацієнтам відмінена на сім днів антигіпертензивна терапія, після чого проведені лабораторно-інструментальні дослідження.

Пацієнти були розподілені на дві групи методом конвертів по 25 у кожній. Першій групі $(\mathrm{n}=25)$ призначено фіксовану потрійну комбінацію таблетки Вал/ Амло/ГХТ. Препарат призначався по 1 таблетці (160 мг валсартану/5 мг амлодипіну/12,5 мг гідрохлортіазиду) один раз на добу, вранці, протягом одного місяця.

Пацієнти другої групи (n=25) отримували за аналогічною схемою подвійну фіксовану комбінацію препарату Вал/Амло. Препарат призначався по 1 таблетці (160 мг валсартану/5 мг амлодипіну) один раз на добу, вранці, протягом одного місяця.

За необхідності, якщо не було досягнення цільового рівня офісного АТ менше 140/90 мм рт. ст., доза титрувалась до добової дози 320/10/12,5 мг (валсартан/ амлодипін/гідрохлортіазид) на фіксованій потрійній комбінації та до 320/10 мг (валсартан/амлодипін) на фіксованій подвійній комбінації. Через три місяці лікування відбувався контроль терапії.

Під час дослідження не дозволявся прийом інших антигіпертензивних препаратів, великої кількості рідини, нестероїдних та стероїдних протизапальних препаратів, симпатоміметичних препаратів. Дозволяється приймати ацетилсаліцилову кислоту та статини за показами на розсуд лікаря.

При кожному візиті проводився контроль прийому ліків, підраховували кількість прийнятих пацієнтом таблеток та кількість днів, що пройшло від попереднього візиту. Якщо коефіцієнт прихильності до лікування (кількість випитих таблеток/кількість днів прийому) був менше 0,75 , пацієнт виключався із дослідження.

Статистичну обробку результатів проведено після створення баз даних у системах Microsoft Excel. Середні показники обстежених пацієнтів визначені за допомогою пакета аналізу в системі Microsoft Excel. Усі інші статистичні розрахунки проведені за допомогою програми SPSS 21.0. Нормальність рядів визначалася за допомогою критерію Шапіро-Уілка. При нормальному розподілі достовірність різниці середніх на етапах лікування визначалася за допомогою парного двовибіркового тесту, достовірність різниці між групами - за допомогою незалежного t-тесту для середніх після визначення характеру розподілу показників. Ефективність та різниця у групах за розподілом наявності тієї або іншої ознаки оцінювалася за дихометричною перемінною за допомогою критерію $\chi 2$.

Результати дослідження та їх обговорення. Основні клініко-демографічні показники пацієнтів обох груп представлені в таблиці 2. Тільки $5(10 \%)$ пацієнтів мали нормальну масу тіла, 17 (34\%) пацієнтів мали надлишкову масу тіла, 33 (56\%) пацієнти мали ожиріння різного ступеня тяжкості, 19 (38\%) пацієнтів - ожиріння I ступеня, 6 (12\%) пацієнтів - ожиріння II ступеня, 3 (6\%) пацієнти - ожиріння III ступеня. Тобто, серед наших пацієнтів із помірною та тяжкою гіпертензією, які потребували прийому подвійної та потрійної комбінації, переважали пацієнти з надмірною масою тіла та ожирінням.

Таблиця 2

Клініко-демографічна характеристика паціснтів обох груп на початку дослідження (M $\pm \mathrm{m})$

\begin{tabular}{|c|c|c|c|}
\hline Показники & $\begin{array}{c}\text { Валсар- } \\
\text { тан/амло- } \\
\text { дипін }\end{array}$ & $\begin{array}{c}\text { Валсартан/ } \\
\text { амлодипін/ } \\
\text { гідрохлорті- } \\
\text { азид }\end{array}$ & P \\
\hline Жінки/чоловіки & $54,2 / 45,8 \%$ & $44,6 / 55,4 \%$ & НД \\
\hline $\begin{array}{c}\text { Тривалість АГ, } \\
\text { роки }\end{array}$ & $8,65 \pm 1,46$ & $8,73 \pm 1,19$ & НД \\
\hline Вік, роки & $57,9 \pm 2,3$ & $54,1 \pm 2,6$ & НД \\
\hline ІМТ, кг/м2 & $30,1 \pm 0,9$ & $32,4 \pm 0,9$ & НД \\
\hline $\begin{array}{c}\text { Офісний САТ, } \\
\text { мм рт.ст. }\end{array}$ & $159,1 \pm 2,9$ & $164,1 \pm 1,9$ & НД \\
\hline $\begin{array}{c}\text { Офісний ДАТ, } \\
\text { мм рт.ст. }\end{array}$ & $96,9 \pm 2,0$ & $99,8 \pm 1,8$ & НД \\
\hline $\begin{array}{c}\text { Офісна ЧСС, } \\
\text { мм рт.ст. }\end{array}$ & $69,0 \pm 1,9$ & $72,2 \pm 1,9$ & НД \\
\hline Палять, \% & $4,2 \%$ & $7,7 \%$ & НД \\
\hline 24САТ, мм рт.ст. & $143.5 \pm 2.0$ & $144.0 \pm 1.5$ & НД \\
\hline 24ДАТ, мм рт.ст. & $91.5 \pm 1.8$ & $92.8 \pm 1.9$ & НД \\
\hline 24ЧСС, уд/хв & $70.3 \pm 2.2$ & $72.1 \pm 1.9$ & НД \\
\hline $\begin{array}{c}\text { Вживають алко- } \\
\text { голь, \% }\end{array}$ & $25 \%$ & $23,1 \%$ & НД \\
\hline $\begin{array}{c}\text { Приймають } \\
\text { статини, \% }\end{array}$ & $58,3 \%$ & $46,2 \%$ & НД \\
\hline $\begin{array}{c}\text { Приймають } \\
\text { ацетилсаліцило- } \\
\text { ву кислоту, \% }\end{array}$ & $25 \%$ & $25 \%$ & НД \\
\hline
\end{tabular}

На початку дослідження 25 пацієнтів (50\%) приймали подвійну терапію Вал/Амло 5/160 мг один раз на добу та 25 пацієнтів (50\%) приймали потрійну комбінацію Вал/ Амло/ГХТ у дозі 5/160/12,5 мг один раз на добу. 
У групі подвійної терапії 8 (32\%) пацієнтів потребували титрації дози, а $68 \%$ пацієнтів залишилися на початковій подвійній комбінації. У трьох пацієнтів із групи подвійної комбінації виникли побічні ефекти, що потребували відміни препарату: в одного пацієнта виник набряк Квінке після прийому першої дози препарату, що було зумовлено реакцією на амлодипін, в одного пацієнта виникла тахікардія, через що він відмовився від прийому препарату, ще в одного пацієнта виникло різке зниження артеріального тиску, через що він також відмовився від прийому препарату. У групі потрійної терапії 15 паціснтів (60\%) потребували титрації дози, а $40 \%$ пацієнтів залишилися на початковій потрійній комбінації. У чотирьох пацієнтів із групи потрійної комбінації виникли побічні ефекти, що потребували відміни препарату: у двох пацієнтів виникли набряки гомілок, що потребувало відміни препарату та у двох пацієнтів виникла тахікардія, через що вони відмовилися від прийому препарату. Таким чином, 46 \% пацієнтів у нашому дослідженні потребували титрації початкової дози препарату. Відміна препарату спостерігалась у семи пацієнтів (14\%).

На фоні терапії подвійною та потрійною комбінацією Вал/Амло/ГХТ в загальній групі зниження офісного САТ/ДАТ на етапах одного місяця, двох місяців, трьох місяців склало -16,7/14,9 мм рт.ст., - 33,9/19,5 мм рт.ст., - 35,6/22,5 мм рт.ст. відповідно $(\mathrm{p}<0,05)$ для усіх значень. Зміни офісної ЧСС були недостовірні наприкінці дослідження.

На фоні терапії подвійною та потрійною комбінацією Вал/Амло/ГХТ у загальній групі зниження АТ при добовому моніторуванні САТ/ДАТ через три місяці терапії склало -20,0/18,6 мм рт.ст., (p<0,05). Зміни добової ЧСС були недостовірні - 71,5 уд/хв на початку дослідження та 68,3 уд/хв наприкінці дослідження.

При аналізі динаміки АТ при добовому моніторуванні окремо у пацієнтів, що приймали подвійну комбінацію Вал/Амло порівняно з потрійною комбінацією Вал/Амло/ГХТ, ми виявили достовірне значне зниження 24САТ/ДАТ на фоні терапії Вал/Амло - 18,0/16,1 мм рт.ст., $(\mathrm{p}<0,05)$ та за денний та нічний періоди - 19,4/17,8 мм рт. ст. та $-17,0 / 12,1$ мм рт. ст. відповідно, $(\mathrm{p}<0,05)$ для усіх значень. Аналогічні, але більш виражені зміни, спостерігались на фоні потрійної комбінованої терапії Вал/Амло/ГХТ. Так, зниження 24САТ/ДАТ через три місяці терапії склало 23,8/20,7 мм рт.ст., а зниження AT за денний та нічний періоди - 27,4/22,6 мм рт. ст., та $-20,5 / 18,2$ мм рт. ст. відповідно $(\mathrm{p}<0,05)$ для усіх значень. Різниця через три місяці склала 5,6/4,6 мм рт. ст., 8/4,8 мм рт. ст., та 3,5/6,1 мм рт. ст. відповідно за весь період, денний та нічний період між групами наприкінці періоду лікування. Зміни ЧСС при ДМАТ були недостовірними. Дані представлені на рисунках 1 та 2 та таблиці 3.

Досягнення цільового рівня офісного АТ наприкінці періоду спостереження в загальному по групі спостерігалось у 93,3 \% пацієнтів. У групі подвійної терапії досягнення цільового офісного АТ становило 90,9\%, у групі потрійної комбінації - у 95,7\% пацієнтів.

Досягнення цільового рівня АТ при добовому моніторуванні становилов у цілому по групі 86\%. У групі подвійної терапії Вал/Амло досягнення цільового АТ

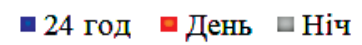

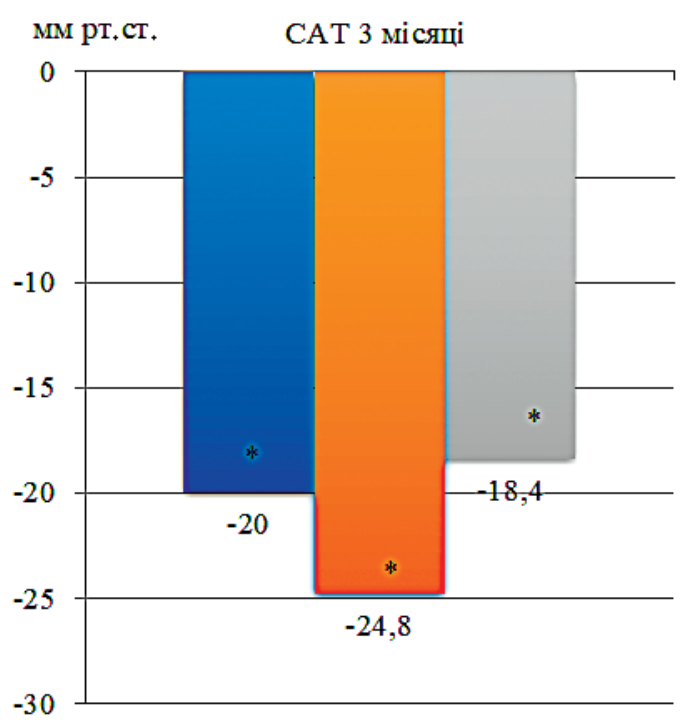

-24 год

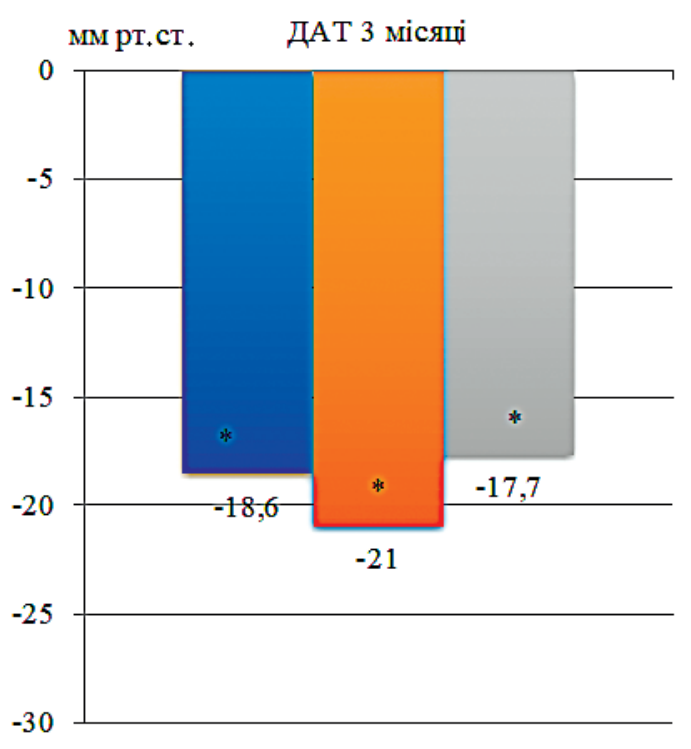

* - p<0,05 порівняно з початком

Рис. 1. Динаміка артеріального тиску при добовому моніторуванні в загальній групі 
Original research

Таблиця 3

Динаміка добового моніторування артеріального тиску на подвійній та потрійній фіксованій комбінації через три місяці лікування

\begin{tabular}{|c|c|c|c|c|c|c|}
\hline & \multicolumn{2}{|c|}{ Валсартан/амлодипін } & \multirow[b]{2}{*}{$\mathrm{P}$} & \multicolumn{2}{|c|}{$\begin{array}{c}\text { Валсартан/амлодипін/ } \\
\text { гідрохлортіазид }\end{array}$} & \multirow[b]{2}{*}{$\mathrm{P}$} \\
\hline & До & Після & & До & Після & \\
\hline 24CAT & $143.5 \pm 2.0$ & $125.5 \pm 1.7$ & 0.000 & $144.0 \pm 1.5$ & $120.2 \pm 1.4$ & 0.000 \\
\hline 24ДАТ & $91.5 \pm 1.8$ & $75.4 \pm 2.0$ & 0.002 & $92.8 \pm 1.9$ & $72.1 \pm 2.1$ & 0.000 \\
\hline 24ПАТ & $57.5 \pm 2.0$ & $50.8 \pm 1.7$ & 0.007 & $58.3 \pm 2.2$ & $48.2 \pm 1.4$ & 0.010 \\
\hline 24макСАТ & $185.6 \pm 5.8$ & $165.0 \pm 3.2$ & 0.010 & $189.2 \pm 4.0$ & $158.1 \pm 2.0$ & 0.000 \\
\hline 24макДАТ & $110.8 \pm 2.6$ & $104.9 \pm 3.2$ & НД & $116.5 \pm 4.4$ & $102.4 \pm 2.8$ & 0.009 \\
\hline 24мінСАТ & $103.1 \pm 2.3$ & $91.7 \pm 2.2$ & 0.001 & $105.7 \pm 2.4$ & $89.3 \pm 2.1$ & 0.000 \\
\hline 24мінДАТ & $56.8 \pm 1.9$ & $49.4 \pm 1.6$ & 0.005 & $58.9 \pm 2.0$ & $49.7 \pm 1.7$ & 0.002 \\
\hline $24 \mathrm{cpЧCC}$ & $70.3 \pm 2.2$ & $66.9 \pm 1.4$ & НД & $72.1 \pm 1.9$ & $69.8 \pm 1.9$ & НД \\
\hline 24макЧСС & $98.4 \pm 3.9$ & $91.9 \pm 3.2$ & НД & $101.2 \pm 4.6$ & $108.4 \pm 4.3$ & НД \\
\hline 24мінЧСС & $54.4 \pm 1.5$ & $51.7 \pm 1.4$ & НД & $58.1 \pm 1.5$ & $52.9 \pm 1.1$ & 0.004 \\
\hline срСАТд & $144.1 \pm 1.6$ & $124.7 \pm 1.2$ & $<0.001$ & $146.9 \pm 2.2$ & $119.5 \pm 1.6$ & $<0.001$ \\
\hline срДАТд & $94.3 \pm 2.2$ & $76.5 \pm 1.9$ & $<0.001$ & $98.6 \pm 2.1$ & $76.0 \pm 2.0$ & 0.001 \\
\hline срПАТд & $55.1 \pm 2.3$ & $48.3 \pm 1.5$ & 0.011 & $58.3 \pm 2.2$ & $51.7 \pm 2.0$ & 0.031 \\
\hline макСАТд & $178.1 \pm 4.5$ & $158.4 \pm 4.3$ & $<0.001$ & $185.2 \pm 5.9$ & $92.9 \pm 3.0$ & $<0.001$ \\
\hline макДАТд & $114.0 \pm 4.7$ & $102.0 \pm 2.8$ & 0.027 & $110.5 \pm 2.7$ & $104.8 \pm 3.1$ & НД \\
\hline мінСАТд & $108.9 \pm 2.8$ & $92.0 \pm 2.1$ & $<0.001$ & $107.1 \pm 2.8$ & $96.6 \pm 2.5$ & 0.004 \\
\hline мінДАТд & $63.5 \pm 2.0$ & $54.1 \pm 1.9$ & 0.004 & $62.7 \pm 2.9$ & $55.0 \pm 2.6$ & НД \\
\hline срЧССд & $76.4 \pm 2.4$ & $74.9 \pm 2.1$ & НД & $74.5 \pm 2.5$ & $73.5 \pm 3.3$ & НД \\
\hline макЧССд & $100.1 \pm 4.8$ & $108.4 \pm 4.3$ & НД & $98.3 \pm 4.0$ & $92.9 \pm 3.0$ & НД \\
\hline мінЧССд & $62.5 \pm 1.8$ & $56.5 \pm 1.5$ & 0.007 & $58.3 \pm 1.8$ & $53.8 \pm 1.4$ & 0.037 \\
\hline срСАТн & $132.3 \pm 2.1$ & $115.3 . \pm 2.5$ & $<0.001$ & $135.6 \pm 2.6$ & $115.1 \pm 2.1$ & $<0.001$ \\
\hline срДАТн & $78.6 \pm 2.0$ & $66.5 \pm 2.6$ & $<0.001$ & $81.9 \pm 2.0$ & $63.7 \pm 2.1$ & 0.004 \\
\hline срПАТн & $53.6 \pm 2.3$ & $47.8 \pm 1.5$ & 0.029 & $55.5 \pm 1.8$ & $47.1 \pm 1.4$ & 0.006 \\
\hline макСАТн & $163.3 \pm 3.7$ & $131.1 \pm 3.5$ & $<0.001$ & $160.8 \pm 3.7$ & $141.0 \pm 3.7$ & 0.001 \\
\hline макДАТн & $100.3 \pm 3.9$ & $79.8 \pm 3.5$ & 0.001 & $95.8 \pm 2.3$ & $86.4 \pm 3.1$ & 0.014 \\
\hline мінСАТн & $108.9 \pm 2.8$ & $94 . \pm 2.3$ & $<0.001$ & $107.1 \pm 2.8$ & $98.3 \pm 2.1$ & 0.001 \\
\hline мінДАТн & $61.0 \pm 2.1$ & $50.9 \pm 1.7$ & 0.001 & $61.5 \pm 3.0$ & $53.3 \pm 1.7$ & 0.035 \\
\hline срЧССн & $66.1 \pm 1.5$ & $61.3 \pm 1.5$ & 0.015 & $62.0 \pm 1.8$ & $61.3 \pm 1.5$ & НД \\
\hline макЧССн & $82.4 \pm 2.8$ & $74.6 \pm 2.8$ & НД & $77.5 \pm 3.1$ & $72.7 \pm 2.5$ & НД \\
\hline мінЧССн & $58.3 \pm 1.5$ & $53.2 \pm 1.2$ & 0.007 & $56.1 \pm 1.8$ & $53.2 \pm 1.3$ & НД \\
\hline
\end{tabular}

Примітка: 24 - дані за весь період, д - денний період, н - нічний період

при ДМАТ становило 77,3\%, у групі потрійної комбінації Вал/Амло/ГХТ - 95,2\% пацієнтів. Таким чином, потрійна фіксована комбінація була більш ефективною в зниженні АТ при офісному вимірюванні та при добовому моніторуванні через три місяці лікування.

Дане дослідження показало, що при прийомі подвійної (на основі валсартану та амлодипіну) або потрійної (на основі валсартану, амлодипіну та гідрохлортіазиду) фіксованої комбінованої терапії відбувалося значне достовірне зниження АТ при добовому моніторуванні у пацієнтів із помірною та тяжкою АГ. Зниження
24САТ/ДАТ у загальному по групі склало 20,0/18,6 мм рт. ст. $(\mathrm{p}<0,05)$ та $24,8 / 21,0$ мм рт. ст. $(\mathrm{p}<0,05)$ за денний період та 18,4/17,7 мм рт.ст. $(\mathrm{p}<0,05)$ - за нічний період. На подвійній фіксованій комбінації (валсартан/ амлодипін) зниження 24САТ/ДАТ склало 18,0/16,1 мм рт. ст. $(\mathrm{p}<0,05)$ та $19,4 / 17,8$ мм рт. ст. $(\mathrm{p}<0,05)$ за денний період та 17,0/12,1 мм рт.ст. $(\mathrm{p}<0,05)$ - за нічний період. На потрійній фіксованій комбінації (Вал/Амло/ ГХТ) зниження 24САТ/ДАТ склало 23,8/20,7 мм рт. ст. $(\mathrm{p}<0,05)$ та 17,8/22,6 мм рт. ст. $(\mathrm{p}<0,05)$ за денний період та 20,5/18,2 мм рт.ст. $(\mathrm{p}<0,05)$ - за нічний період. 


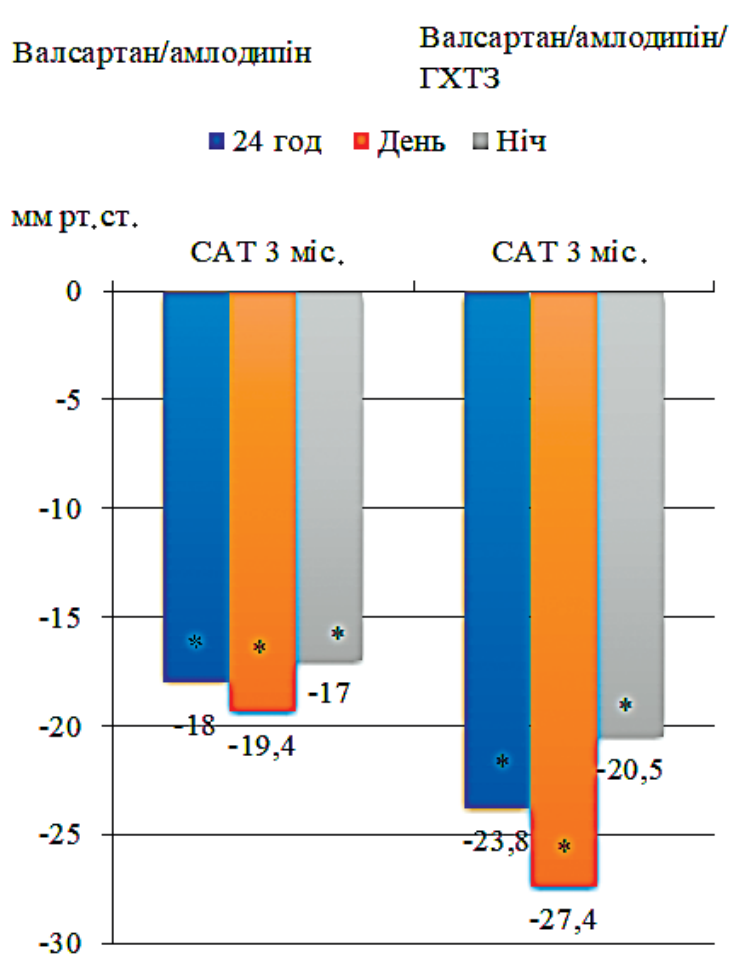

Валсартан/амлоднпін/ ГХТ3

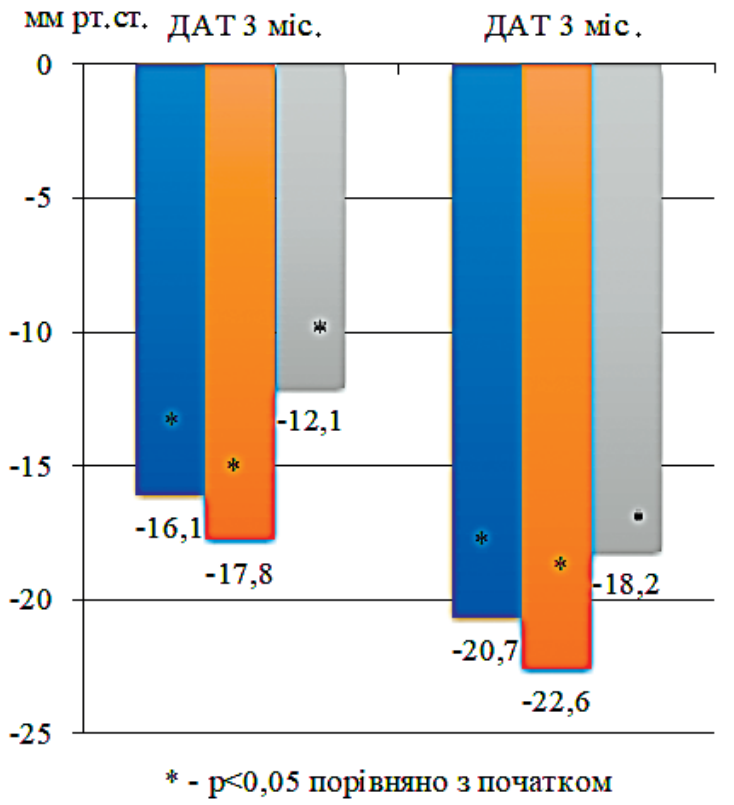

Рис. 2. Динаміка артеріального тиску при добовому моніторуванні в групах подвійної та потрійної фіксованої комбінації

У цілому на терапії Вал/Амло та Вал/Амло/ГХТ 86\% усіх досліджуваних пацієнтів досягли цільового рівня АТ при ДМАТ. На подвійній фіксованій комбінації (Вал/Амло) досягнення цільового рівня АТ при ДМАТ становило 77,3 \%, причому у групі потрійної фіксованої комбінації (Вал/Амло/ГХТ) кількість таких пацієнтів була більшою - 95,2\%.

Ефективність фіксованої подвійної комбінації Вал/ Амло була широко вивчена в багатьох рандомізваних дослідженнях. Так, проведено 13 великих досліджень більше 60 тис. пацієнтів у 26 країнах світу $[20,21]$. Ефективність потрійної фіксованої комбінації Вал/ Амло/ГХТ в одній таблетці доведена в п'яти великих рандомізованих дослідженнях, що включали 1500 пацієнтів. Також проведено два дослідження ЕХСІТЕ та SIMPLIFY фіксованої комбінації Вал/Амло/ГХТ в одній таблетці у 14 країнах світу на 8000 пацієнтів [21, 22].

Don Poldermans зі співавторами та B. Waeber порівнювали ефективність та переносимість комбінації Вал/Амло та лізиноприл/ГХТ у пацієнтів з АГ ІІ стадії протягом шести тижнів. Зниження офісного САТ/ДАТ у групі Вал/Амло становило 35,8/28,6 мм рт.ст., у групі лізиноприл/ГХТ - 31,8/27,6 мм рт.ст. Досягнення цільових рівнів АТ становило 67,2 та 56,1 \% відповідно в групах. Побічні реакції зафіксовані в 40,6 \% пацієнтів у групі Вал/Амло та в $31,8 \%$ - у групі лізиноприл/ ГXT [23, 24].

У дослідженні EXTRA S. Oparil зі співавт. досліджували протягом 12 тижнів вплив лікування комбінацією Вал/Амло (5/320 мг, зі збільшенням до 10/320 мг у групі інтенсивного лікування або 5/160 мг) у пацієнтів із неконтрольованою АГ на фоні монотерапії блокаторами рецепторів до АГ ІІ (олмесартан 20 або 40 мг) [26]. При необхідності додавався ГХТ 12,5-25 мг. Середні цифри офісного АТ на початку дослідження в групі інтенсивного лікування становили 163,9/95,5 мм рт.ст., у групі помірного лікування - 163,3/95,0 мм рт.ст. Інтенсивне лікування достовірно більше знижувало цифри АТ - 29,0/14,8 мм рт.ст. порівняно з групою помірного лікування - 25,3/12,3 мм рт.ст. Побічні реакції спостерігались у $36,3 \%$ випадків та в $37,6 \%$ випадків у групах інтенсивного та помірного лікування відповідно. Периферійні набряки були частіше виражені в групі інтенсивного лікування (8,7 \% випадків) порівняно 3 групою помірного лікування (4,5 \%) [25].

Дослідження ЕXCITE (9794 пацієнти, середній вік 53,2 року) проводилося для оцінки ефективності та безпечності подвійної та потрійної комбінації Амл/Вал та Амл/Вал/ГХТ в одній таблетці у пацієнтів із АГ у різних країнах на Близькому Сході та Азії [21]. Наприкінці 26-го тижня при прийомі подвійної фіксованої комбінації Вал/Амло зниження офісного САТ/ДАТ склало - 31,0/16,6 мм рт.ст., а на фоні прийому фіксованої потрійної комбінації Вал/Амло/ГХТ - 36,6/17,8 мм рт. ст. У 11,2\% пацієнтів спостерігалися побічні реакції на подвійній терапії та у $6,1 \%$ - на потрійній терапії. Найчастішими були периферійні набряки. Досягнення цільового рівня АТ було у 52,8\% для подвійної терапії та у 54,5\% для потрійної терапії.

D. Calhoun зі співавт. [7,8] протягом восьми тижнів 


\section{Original research}

лікували пацієнтів потрійною (Вал/Амло/ГХТ) або подвійною терапією (Вал/Амло, амлодипін/ГХТ, валсартан/ГХТ). Досягнення цільових рівнів АТ відзначено в $71 \%$ пацієнтів із потрійною терапією і в 45-54 \% - у пацієнтів із подвійною терапією. У нашому дослідженні досягнення цільових рівнів було у 77,3\% пацієнтів на подвійній фіксованій комбінації та у 95,2\% пацієнтів - на потрійній комбінації.

S. Matsuda зі співав. [26] вивчали вплив фіксованої комбінації валсартан/кілнідипін протягом 12 місяців у дослідженні НОРЕ-Combi. Побічні реакіції були зафіксовані у 3,77\% пацієнтів. Офісний САТ знизився 3 $149,5 \pm 19,6$ мм рт. ст. до $133,5 \pm 14,8$ мм рт. ст. $(-15.8$ мм рт. ст., $\mathrm{p}<0,01)$ через 12 місяців лікування. Автори дійшли висновку, що фіксована комбінація валсартан/ кілнідипін була безпечною та ефективною.

Наше дослідження довело високу антигіпертензивну ефективність за даними добового моніторування фіксованої потрійної комбінації Вал/Амло/ГХТ та подвійної фіксованої комбінації Вал/Амло у лікуванні пацієнтів із АГ II-III ступеня.

\section{Висновки}

1. Зниження середньодобового артеріального тиску склало 18,0/16,1 мм рт. ст. $(\mathrm{p}<0,05)$ на подвійній (валсартан/амлодипін) та 23,8/20,7 мм рт.ст. $(\mathrm{p}<0,05)$ на потрійній (валсартан/амлодипін/гідрохлортіазид) фіксованній комбінації.

2. Фіксована потрійна комбінація сприяла досягненню цільового рівня артеріального тиску при добовому моніторуванні у 95,2\% випадків, а на фіксованій подвійній комбінації досягнення цільового рівня артеріального тиску при добовому моніторуванні становило 77,3\%.

3. Потрійна комбінація більш ефективна в зниженні артеріального тиску при добовому моніторуванні порівняно $з$ подвійною комбінацією, що не супроводжувалося збільшенням побічних ефектів.

Перспективи подальших досліджень. Визначення подальших перспективних можливостей фіксованих подвійних та потрійних комбінацій у лікуванні пацієнтів iз недосягненням цільових рівнів артеріального тиску в пацієнтів із резистентною гіпертензією.

\section{Конфлікту інтересів немас.}

Список літератури

1. Kearney PM, Whelton M, Reynolds K, Muntner P, Whelton PK, He J. Global burden of hypertension: analysis of worldwide data. Lancet. 2005;365(9455):217-23. DOI: 10.1016/S0140-6736(05)17741-1.

2. Williams B, Mancia G, Spiering W, Agabiti Rosei E, Azizi M, Burnier M, et al. $2018 \mathrm{ESC} / \mathrm{ESH}$ Guidelines for the management of arterial hypertension. Eur Heart J. 2018;39(33):3021-3104. DOI: 10.1093/eurheartj/ ehy339.

3. Mancia G. Initial combination treatment in the $2018 \mathrm{ESC} / \mathrm{ESH}$ hypertension guidelines. Anatol J Cardiol. 2019 Sep;22(3):100-101. DOI: 10.14744/Anatol. J. Cardiol.2019.03292.

4. Tocci G, Presta V, Ferri C, Redon J, Volpe M. Blood Pressure Targets Achievement According to $2018 \mathrm{ESC} / \mathrm{ESH}$ Guidelines in Three European Excellence Centers for Hypertension. High Blood Press Cardiovasc Prev. 2020 Feb;27(1):51-9. DOI: 10.1007/s40292-020-00359-0.

5. Mancia G, Fagard R, Narkiewicz K, Redon J, Zanchetti A, Bohm M, et al. $2013 \mathrm{ESH} / \mathrm{ESC}$ guidelines for the management of arterial hypertension: the Task Force for the Management of Arterial Hypertension of the European
Society of Hypertension (ESH) and of the European Society of Cardiology (ESC). J Hypertens. 2013;31(7):1281-357.

6. Whelton PK, Carey RM, Aronow WS, Casey DE, Collins KJ, Dennison Himmelfarb C, et al. 2017 ACC/AHA/AAPA/ABC/ ACPM/ AGS/APhA/ASH/ASPC/NMA/PCNA guideline for the prevention, detection, evaluation, and management of high blood pressure in adults: a report of the American College of Cardiology/ American Heart Association Task Force on Clinical Practice Guidelines. Hypertension. 2018;71(6):13-115.

7. Calhoun DA, Crikelair NA, Yen J, Glazer RD. Amlodipine/valsartan/ hydrochlorothiazide triple combination therapy in moderate/severe hypertension: secondary analyses evaluating efficacy and safety. Adv Ther. 2009;26(11):1012-23. DOI: 10.1007/s12325-009-0077-7.

8. Calhoun DA, Lacourciere Y, Crikelair N, Jia Y, Glazer RD. Effects of demographics on the antihypertensive efficacy of triple therapy with amlodipine, valsartan, and hydrochlorothiazide for moderate to severe hypertension. Curr Med Res Opin. 2013;29(8):901-10. DOI: 10.1185/03007995.2013.803057.

9. Cushman WC, Bakris GL, White WB, Weber MA, Sica D, Roberts A, et al. A randomized titrate-to-target study comparing fixed-dose combinations of azilsartan medoxomil and chlorthalidone with olmesartan and hydrochlorothiazide in stage-2 systolic hypertension. J Hypertens. 2018 Apr; 36(4): 947-56.

10. Destro M, Luckow A, Samson M, Kandra A, Brunel P. Efficacy and safety of amlodipine/valsartan compared with amlodipine monotherapy in patients with stage 2 hypertension: a randomized, double-blind, multicenter study: the EX-EFFeCTS Study. J Am Soc Hypertens. 2008;2(4):294-302. DOI: 10.1016/j.jash.2008.01.004.

11. Jamerson KA, Bakris GL, Wun CC, Dahlöf B, Lefkowitz M, Manfreda S, et al. Rationale and design of the avoiding cardiovascular events through combination therapy in patients living with systolic hypertension (ACCOMPLISH) trial: the first randomized controlled trial to compare the clinical outcome effects of first-line combination therapies in hypertension. Am J Hypertens. 2004 Sep;17(9):793-801. DOI: 10.1016/j. amjhyper.2004.05.004.

12. Xu SK, Huang QF, Zeng WF, Sheng CS, Li Y, Wang JG. A randomized multicenter study on ambulatory blood pressure and arterialstiffness in patients treated with valsartan/amlodipine or nifedipine GITS. J Clin Hypertens (Greenwich). 2019 Feb;21(2):252-61. DOI: 10.1111/ jch. 13457.

13. Huo Y, Gu Y, Ma G, Guo J, Xiong L, Luo Z, et al. China STudy of valsartan/amlodipine fixed-dose combination-bAsed long-Term blood pressUre management in HypertenSive patients: a one-year registry (China STATUS III). Curr Med Res Opin. 2019 Aug;35(8):1441-49. DOI: 10.1080/03007995.2019.1596630.

14. Kafrawy NE, Rashwan M, Lion K, Khedr K, Nashaat N. Effectiveness and tolerability of fixed dose combination of amlodipine/ valsartan in treatment of hypertension in the real-life setting among Egyptian patients. Egyptian Heart J. 2014;66(1):30-5.

15. Kario K, Tomitani N, Kanegae H, Ishii H, Uchiyama K, Yamagiwa K, et al. Comparative effects of an angiotensin II receptor blocker (ARB)/diuretic vs. ARB/calcium-channel blocker combination on uncontrolled nocturnal hypertension evaluated by information and communication technology-based nocturnal home blood pressure monitoring- the NOCTURNE Study. Circ J. 2017;81(7):948-57. DOI: 10.1253/circj.CJ-17-0109.

16. Khan W, Moin N, Iktidar S, Sakrani J, Abid R, Afzal J, et al. Real-life effectiveness, safety, and tolerability of amlodipine/valsartan or amlodipine/valsartan/hydrochlorothiazide single pill combination in patients with hypertension from Pakistan. Ther Adv Cardiovasc Dis. 2014;8(2):45-55.

17. Lins R, Aerts A, Coen N, Hermans C, MacDonald K, Brie H, et al Effectiveness of amlodipine-valsartan single-pill combinations: hierarchical modeling of blood pressure and total cardiovascular disease risk outcomes (the EXCELLENT study). Ann Pharmacother. 2011;45(6):727-39.

18. Flack JM, Calhoun DA, Satlin L, Barbier M, Hilkert R, Brunel P. Efficacy and safety of initial combination therapy with amlodipine/ valsartan compared with amlodipine monotherapy in black patients with stage 2 hypertension: the EX-STAND study. J Hum Hypertens. 2009;23(7):479-89.

19. Asmar R, Gosse P, Quere S, Achouba A. Efficacy of morning and evening dosing of amlodipine/valsartan combination in hypertensive 
patients uncontrolled by $5 \mathrm{mg}$ of amlodipine. Blood Press Monit 2011;16(2):80-6. DOI: 10.1097/MBP.0b013e328344c6db.

20. Baser O, Andrews LM, Wang Li, Xie L. Comparison of realworld adherence, healthcare resource utilization and costs for newly initiated valsartan/amlodipine single-pill combination versus angiotensin receptor blocker/calcium channel blocker freecombination therapy. J Med Econ. 2011;14(5):576-83. DOI: 10.3111/13696998.2011.596873.

21. Assaad-Khalil SH, Nashaat N. Real-life Effectiveness and Safety of Amlodipine/Valsartan Single-pill Combination in Patients with Hypertension in Egypt: Results from the EXCITE Study. Drugs Real World Outcomes. 2016;3(3):307-15. DOI: 10.1007/s40801-016-0082-5.

22. Destro M, Cagnoni F, D'Ospina A, Ricci AR, Demichele E, Peros E, et al. Role of valsartan, amlodipine and hydrochlorothiazide fixed combination in blood pressure control: an update. Vasc Health Risk Manag. 2010 Apr 15;6:253-60. DOI: 10.2147/vhrm.s6805.

23. Poldermans D, Glazes R, Kargiannis S, Wernsing M, Kaczor J, Chiang YT, et al. Tolerability and blood pressure-lowering efficacy of the combination of amlodipine plus valsartan compared with lisinopril plus hydrochlorothiazide in adult patients with stage 2 hypertension. Clin Ther. 2007 Feb;29(2):279-89. DOI: 10.1016/j.clinthera.2007.02.003.

24. Waeber B, Ruilope LM. Amlodipine and valsartan as components of a rational and effective fixed-dose combination. Vasc Health Risk Manag. 2009;5(1):165-74. DOI: 10.2147/vhrm.s3134.

25. Oparil S, Giles T, Ofili EO, Pitt B, Seifu Y, Hilkert R, et al. Moderate versus intensive treatment of hypertension with amlodipine/ valsartan for patients uncontrolled on angiotensin receptor blocker monotherapy. J Hypertens. 2011 Jan; 29(1):161-70. DOI: 10.1097/ HJH.0b013e32834000a7.

26. Matsuda S, Nagahama S, Kurose Y, Wakabayashi M, Sugii $\mathrm{H}$, Teshima $\mathrm{T}$, et al. A post-marketing survey evaluating the safety and efficacy of a fixed-dose single-pill combination of cilnidipine and valsartan in patients with hypertension: Real-world JSH 2014 and 2019 implementations. Clin Exp Hypertens. 2020 Jan 22:1-10. DOI: 10.1080/10641963.2020.1714641.

\section{Відомості про авторів}

Рековець Оксана Леонідівна - старший науковий співробітник відділу симптоматичних гіпертензій ДУ "ННЦ

"Інститут кардіології імені академіка М.Д. Стражеска" НАМН України, м. Київ, Україна.

Сіренко Юрій Миколайович - професор, керівник відділу симптоматичних гіпертензій ДУ "ННЦ "Інститут кардіології імені академіка М.Д. Стражеска" НАМН України, м. Київ, Україна.

Торбас Олена Олександрівна - науковий співробітник відділу симптоматичних гіпертензій ДУ "ННЦ "Інститут кардіології імені академіка М.Д. Стражеска" НАМН України, м. Київ, Україна.

Кушнір Світлана Миколаївна - науковий співробітник відділу симптоматичних гіпертензій ДУ "ННЦ "Інститут кардіології імені академіка М.Д. Стражеска" НАМН України, м. Київ, Україна.

Примак Галина Федорівна - лікар вищої категорії, к.м.н. відділу симптоматичних гіпертензій ДУ "ННЦ "Інститут кардіології імені академіка М.Д. Стражеска" НАМН України, м. Київ, Україна.

\section{Сведения об авторах}

Рековец Оксана Леонидовна - старший научный сотрудник отдела симптоматических гипертензий ГУ "ННЦ" Институт кардиологии имени академика Н.Д. Стражеско "НАМН Украины, г. Киев, Украина.

Сиренко Юрий Николаевич - профессор, руководитель отдела симптоматических гипертензий ГУ "ННЦ" Институт кардиологии имени академика Н.Д. Стражеско "НАМН Украины, г. Киев, Украина.

Торбас Елена Александровна - научный сотрудник отдела симптоматических гипертензий ГУ "ННЦ" Институт кардиологии имени академика Н.Д. Стражеско "НАМН Украины, г. Киев, Украина.

Кушнир Светлана Николаевна - научный сотрудник отдела симптоматических гипертензий ГУ "ННЦ «Институт кардиологии имени академика Н.Д. Стражеско "НАМН Украины, г. Киев, Украина.

Примак Галина Федоровна - к.м.н., врач высшей категории отдела симптоматических гипертензий ГУ "ННЦ" Институт кардиологии имени академика Н.Д. Стражеско "НАМН Украины, г. Киев, Украина.

\section{Informations about the authors}

Rekovets Oksana - MD, PhD, Senior Researcher, Department of Symptomatic Hypertension Institute of Cardiology named after ND Strazhesko of the National Academy of Medical Sciences of Ukraine, Kyiv, Ukraine, recovets@ukr.net, +38095275 5897 - mob, +38 0442497040 - work.

Sirenko Yuriy - Professor, Head of the Department of Symptomatic Hypertension Institute of Cardiology named after ND Strazhesko of the National Academy of Medical Sciences of Ukraine, Kyiv, Ukraine.

Torbas Olena - MD, PhD, Researcher, Department of Symptomatic Hypertension Institute of Cardiology named after ND Strazhesko of the National Academy of Medical Sciences of Ukraine, Kyiv, Ukraine.

Kushnir Svitlana - MD, PhD, Researcher, Department of Symptomatic Hypertension Institute of Cardiology named after ND Strazhesko of the National Academy of Medical Sciences of Ukraine, Kyiv, Ukraine.

Primak Galina - MD, PhD Department of Symptomatic Hypertension

Institute of Cardiology named after ND Strazhesko of the National Academy of Medical Sciences of Ukraine, Kyiv, Ukraine. 